\title{
International regimes, transactions, and change: embedded liberalism in the postwar economic order
}

John Gerard Ruggie

A philosopher is someone who goes into a dark room at night, to look for a black cat that isn't there. A theologian does the same thing, but comes out claiming he found the cat.

Nick Philips, "The Case of the Naked Quark," TWA Ambassador Magazine, October 1980.

One of our major purposes in this volume is to establish whether we, as students of international regimes, most resemble the philosopher, the theologian or, as most of us would like to believe, the social scientistsuspecting from the beginning that there is a black cat in there somewhere, and emerging from the room with scratches on the forearm as vindication. This article consists of another set of scratches, together with what 1 hope will be persuasive reasoning and demonstration that a black cat put them there.

My focus is on how the regimes for money and trade have reflected and affected the evolution of the international economic order since World War II. Let me state my basic approach to this issue at the outset, for, as Krasner shows in the Introduction, a good deal of the disagreement and confusion

I have benefited from the comments and suggestions of a large number of friends, colleagues, and fellow travelers, and am particularly indebted to the detailed written remarks of Catherine Gwin, Ernst Haas, Robert Keohane, Stephen Krasner, and Susan Strange, as well as to Albert Fishlow's constructive criticism at the Palm Springs conference. Research for this article was made possible by financial support from the Rockefeller Foundation and the Ira D. Wallach Chair of World Order Studies at Columbia University.

International Organization 36, 2, Spring 1982

0020-8183/82/020379-37 \$1.50

(C) 1982 by the Massachusetts Institute of Technology 
about international regimes stems from deeper epistemological and even ontological differences among observers.

International regimes have been defined as social institutions around which actor expectations converge in a given area of international relations. ${ }^{1}$ Accordingly, as is true of any social institution, international regimes limit the discretion of their constituent units to decide and act on issues that fall within the regime's domain. And, as is also true of any social institution, ultimate expression in converging expectations and delimited discretion gives international regimes an intersubjective quality. To this extent, international regimes are akin to language - we may think of them as part of "the language of state action." 2 The constituent units of a regime, like speakers of a common language, generally have little difficulty in determining what even an entirely new usage signifies. Should it be technically inappropriate or incorrect, they nevertheless may still "understand" it -in the dual sense of being able to comprehend it and willing to acquiesce in it. In sum, we know international regimes not simply by some descriptive inventory of their concrete elements, but by their generative grammar, the underlying principles of order and meaning that shape the manner of their formation and transformation. Likewise, we know deviations from regimes not simply by acts that are undertaken, but by the intentionality and acceptability attributed to those acts in the context of an intersubjective framework of meaning. ${ }^{3}$

The analytical components of international regimes we take to consist of principles, norms, rules, and procedures. As the content for each of these terms is specified, international regimes diverge from social institutions like language, for we do not normally attribute to language any specific "consummatory" as opposed to "instrumental" values. ${ }^{4}$ Insofar as international regimes embody principles about fact, causation, and rectitude, as well as political rights and obligations that are regarded as legitimate, they fall closer to the consummatory end of the spectrum, into the realm of political authority. Thus, the formation and transformation of international regimes may be said to represent a concrete manifestation of the internationalization of political authority. ${ }^{5}$

${ }^{1}$ Oran R. Young, "International Regimes: Problems of Concept Formation," World Politics 32 (April 1980); and Stephen D. Krasner's introduction to this volume.

2 This phrase is taken from Bruce Andrews's application of the linguistic metaphor to the study of foreign policy: "The Language of State Action," International Interactions 6 (November 1979).

${ }^{3}$ Cf. Noam Chomsky, Current Issues in Linguistic Theory (The Hague: Mouton, 1964), chap. 1.

${ }^{4}$ These are derived from the standard Weberian distinction between Wert- and Zweckrational. Max Weber, Economy and Society, ed. by Guenther Roth and Claus Wittich (Berkeley: University of California Press, 1978), pp. 24-26.

${ }^{5}$ Discussions of political authority often fuse the very meaning of the concept with one of its specific institutional manifestations, that expressed in super-subordinate relations. But, as demonstrated repeatedly in organization theory and recognized by Weber, authority rests on a form of legitimacy that ultimately can derive only from a community of interests. Chester Barnard has carried this line of reasoning the furthest: "Authority is another name for the willingness and capacity of individuals to submit to the necessities of cooperative systems." The 
What is the "generative grammar" that shapes the internationalization of political authority? The most common interpretation has been stated succinctly by Kenneth Waltz: the elements of international authority, he maintains, "are barely once removed from the capability that provides [their] foundation. . ." ${ }^{6}$ On this interpretation others, in turn, have built what now amounts to a prevalent model of the formation and transformation of international economic regimes. In its simplest form, the model makes this prediction: if economic capabilities are so concentrated that a hegemon exists, as in the case of Great Britain in the late 19th century and the U.S.A. after World War II, an "open" or "liberal" international economic order will come into being. ${ }^{7}$ In the organization of a liberal order, pride of place is given to market rationality. This is not to say that authority is absent from such an order. It is to say that authority relations are constructed in such a way as to give maximum scope to market forces rather than to constrain them. Specific regimes that serve such an order, in the areas of money and trade, for example, limit the discretion of states to intervene in the functioning of selfregulating currency and commodity markets. These may be termed "strong" regimes, because they restrain self-seeking states in a competitive international political system from meddling directly in domestic and international economic affairs in the name of their national interests. And the strength of these regimes, of course, is backed by the capabilities of the hegemon. If and as such a concentration of economic capabilities erodes, the liberal order is expected to unravel and its regimes to become weaker, ultimately being replaced by mercantilist arrangements, that is, by arrangements under which the constituent units reassert national political authority over transnational economic forces. If the order established by British economic supremacy in the 19th century and that reflecting the supremacy of the United States after World War II illustrate liberal orders with strong regimes, the interwar period illustrates the darker corollary of the axiom.

I do not claim that this model is fundamentally wrong. But it does not take us very far in understanding international economic regimes, and, by extension, the formation and transformation of international regimes in gen-

Functions of the Executive (Cambridge: Harvard University Press, 1968), p. 184. See also the important statement by Peter Blau, "Critical Remarks on Weber's Theory of Authority," American Political Science Review 57 (June 1963). An illustration (though unintended) of how not to think of authority if the concept is to be at all useful in a discussion of international relations is provided by Harry Eckstein, "Authority Patterns: A Structural Basis for Political Inquiry," American Political Science Review 67 (December 1973). More elaborate typologies of forms of authority relations in international regimes may be found in my papers, "International Responses to Technology: Concepts and Trends," International Organization 29 (Summer 1975), and "Changing Frameworks of International Collective Behavior: On the Complementarity of Contradictory Tendencies," in Nazli Choucri and Thomas Robinson, eds., Forecasting in International Relations (San Francisco: W. H. Freeman, 1978).

${ }^{6}$ Theory of International Politics (Reading, Mass.: Addison-Wesley, 1979), p. 88.

${ }^{7}$ The relevant literature is cited in Robert $O$. Keohane, "The Theory of Hegemonic Stability and Changes in International Economic Regimes, 1967-1977," in Ole Holsti et al., eds., Change in the International System (Boulder, Col.: Westview Press, 1980). 
eral. ${ }^{8}$ This is so precisely because it does not encompass the phenomenological dimensions of international regimes.

From this vantage point, I develop three theoretical arguments; each yields an interpretation of central features of the postwar international economic order that is distinct from the prevailing view.

The first concerns the "generative grammar" or what I shall call the "structure" of the internationalization of political authority. Whatever its institutional manifestations, political authority represents a fusion of power with legitimate social purpose. The prevailing interpretation of international authority focuses on power only; it ignores the dimension of social purpose. ${ }^{9}$ The problem with this formulation is that power may predict the form of the international order, but not its content. For example, in the era of the third hegemon in the complex of modern state-system and capitalist-worldeconomy, the Dutch in the 17th century, the condition of hegemony coexisted with mercantilist behavior, ${ }^{10}$ and it would be straining credulity to attribute this difference solely or even mainly to differences in the relative economic supremacy of the three hegemons without discussing differences in social purpose. Moreover, had the Germans succeeded in their quest to establish a "New International Order" after World War II, the designs Hjalmar Schacht would have instituted were the very mirror image of Bretton Woods ${ }^{11}$-obviously, differences in social purpose again provide the key. Lastly, the common tendency to equate the 19th century liberal international economic order and its post-World War II counterpart itself obscures exceedingly important differences in their domestic and international organization, differences that stem from the fact that the one represented laissez-faire liberalism and the other did not. In sum, to say anything sensible about the content of international economic orders and about the regimes that serve them, it is necessary to look at how power and legitimate social purpose become fused to project political authority into the international system. Applied to the post-World War II context, this argument leads me to characterize the international economic order by the term "em-

\footnotetext{
${ }^{8}$ Nor should it be expected to. As Waltz makes clear, his is a theory intended to predict that certain conditioning and constraining forces will take effect within the international system as a whole depending upon variation in its structure, not to account for such "process-level" outcomes as international regimes. Some of the literature cited by Keohane attempts to do more than this, however, though Keohane himself reaches a conclusion that is not at variance with my own.

${ }^{9}$ More accurately, it either assumes social purpose (as in Waltz, Theory of International Politics), or seeks to deduce it from state power (as in Krasner, "State Power and the Structure of International Trade," World Politics 28 [April 1976]).

${ }^{10}$ To my knowledge, the case of Dutch supremacy in the world economy has not been addressed in the "hegemonic stability" literature; but see Immanuel Wallerstein, The Modern World System, vol. 2 (New York: Academic Press, 1980), chap. 2.

${ }^{11}$ A brief description may be found in Armand Van Dormael, Bretton Woods: Birth of a Monetary System (London: Macmillan, 1978), chap. 1. The classic statement of how it actually worked remains Albert O. Hirschman, National Power and the Structure of Foreign Trade, expanded ed. (Berkeley: University of California Press, 1980).
} 
bedded liberalism," which I show to differ from both its classical ancestor and its ignominious predecessor even as it has systematically combined central features of both.

My second theoretical argument concerns the relationship between international economic regimes and developments in the international economy, particularly at the level of private transaction flows. ${ }^{12}$ Conventional structural arguments, whether Realist or Marxist, see transnationalization as a direct reflection of hegemony: high levels of trade and capital flows obtain under the pax Britannica and the pax Americana. The regimes for trade and money are largely epiphenomenal adjuncts that may be invoked to legitimate this outcome, but they have little or no real bearing on it. Conventional liberals, on the other hand, hold that high levels of trade and capital flows will obtain only if there is strict adherence to open international economic regimes, so that these become virtually determinative. Neither formulation is satisfactory.

The relationship between economic regimes and international transaction flows is inherently problematical, because the domain of international regimes consists of the behavior of states, vis-à-vis one another and vis-àvis the market-place, not the market-place itself. Nevertheless, simply on a priori grounds we may argue that because there is no direct relationship, it is highly unlikely that the character of international regimes would have a determinative impact on international transaction flows; and yet, because international regimes do encompass the behavior of states visà-vis the market-place, it stands to reason that they would have some effect on international transaction flows. I contend that the nature of this relationship, at least in the first instance, is one of complementarity. That is to say, international economic regimes provide a permissive environment for the emergence of specific kinds of international transaction flows that actors take to be complementary to the particular fusion of power and purpose that is embodied within those regimes. ${ }^{13}$ The contextual specificity of this complementarity makes equations of the variety "pax Britannica is equal to pax Americana," as well as insistence on universal regime formulae to achieve a given outcome, extremely dubious propositions.

Applying this argument to the postwar international economic order, I conclude that the emergence of several specific developments in transnational economic activities can be accounted for at least in part by their perceived first-order contribution to the regimes for trade and money. ${ }^{14}$ These regimes, then, are neither determinative nor irrelevant, but provide part of the context that shapes the character of transnationalization.

${ }^{12}$ In this connection, see also Charles Lipson's chapter in this volume.

${ }^{13}$ This is not to ignore the possibility that the same developments may have second-order consequences or long-term effects that pose stresses or even contradictions for international economic regimes, a problem which I take up in a later section.

${ }^{14}$ The present formulation of this conclusion owes much to Albert Fishlow's commentary on an earlier version at the Palm Springs Conference, for which I am obliged to him. 
My third theoretical argument concerns the occurrence of change in and of regimes. The prevailing model postulates one source of regime change, the ascendancy or decline of economic hegemons, and two directions of regime change, greater openness or closure. If, however, we allow for the possibility that power and purpose do not necessarily covary, then we have two potential sources of change and no longer any simple one-to-one correspondence between source and direction of change. For example, we could have a situation in which there exists a predominant economic power whose economic program differs fundamentally from that of its leading rivals (e.g., Dutch supremacy in the 17th century). Or, we could have a situation in which power and purpose covary negatively, that is, in which neither a hegemon nor a congruence of social purpose exists among the leading economic powers (the interwar period approximates this case). We could have a situation in which power and purpose covary positively (e.g., Bretton Woods). There remains the situation of no hegemon but a congruence of social purpose among the leading economic powers (albeit imperfectly, the post-1971 international economic order illustrates this possibility).

It is the last possibility that interests me most. It suggests the need for a more nuanced formulation of regime change than is currently available. If and as the concentration of economic power erodes, and the "strength" of international regimes is sapped thereby, we may be sure that the instruments of regimes also will have to change.$^{15}$ However, as long as purpose is held constant, there is no reason to suppose that the normative framework of regimes must change as well. In other words, referring back to our analytical components of international regimes, rules and procedures (instruments) would change but principles and norms (normative frameworks) would not. Presumably, the new instruments that would emerge would be better adapted to the new power situation in the international economic order. But insofar as they continued to reflect the same sense of purpose, they would represent a case of norm-governed as opposed to norm-transforming change.

Applying this argument to the post-1971 period leads me to suggest that many of the changes that have occurred in the regimes for money and trade have been norm-governed changes rather than, as is often maintained, reflecting the collapse of Bretton Woods and a headlong rush into mercantilism. Indeed, in certain cases earlier acts by the hegemon had violated the normative frameworks of these regimes, so that some post-1971 changes may be viewed as adaptive restorations of prior sets of norms in the context of a new and different international economic environment. Both occurrences may to taken to demonstrate what we might call "the relative autonomy" of international regimes (with due apologies to the appropriate quarters).

The various parts of my argument clearly stand or fall together. Ulti-

\footnotetext{
15 The "hegemonic stability" school effectively demonstrates why this is so. See Keohane, "Theory of Hegemonic Stability."
} 
mately, they lead back to my depiction of international authority as reflecting a fusion of power and legitimate social purpose. An historical illustration of this interpretation of the "structure" of international authority therefore serves as my point of departure.

\section{The structure of international authority}

Karl Polanyi's magisterial work, The Great Transformation, was first published in 1944. In it, he developed a distinction between "embedded" and "disembedded" economic orders: "normally, the economic order is merely a function of the social, in which it is contained. Under neither tribal, nor feudal, nor mercantile conditions was there, as we have shown, a separate economic system in society. Nineteenth century society, in which economic activity was isolated and imputed to a distinctive economic motive, was, indeed, a singular departure." 16 The best known international forms taken by this "singular departure" were, of course, the regimes of free trade and the gold standard. What were their bases?

The internationalization of domestic authority relations

Charles Kindleberger, who is justly accorded a leading role in having established the efficacy of the "hegemonic stability" model in his book on the Great Depression, ${ }^{17}$ subsequently managed to write an account of the rise of free trade in western Europe without even mentioning British economic supremacy as a possible source of explanation. ${ }^{18} \mathrm{He}$ focused instead on a fundamental reordering of the relationships between domestic political authority and economic processes. Free trade, he reminds us, was due first of all to the general breakdown of the manor and guild system and the so-called policy of supply, through which a complex structure of social regulations rather than market exchange determined the organization of economic activity at home and abroad. Indeed, the earliest measures undertaken in order to free trade were to dismantle prohibitions on exports, prohibitions that had restricted the outward movement of materials, machinery, and artisans. The bulk of these prohibitions was not removed until well into the 1820 s and $1830 \mathrm{~s}$, and in some instances even later. A second part of the stimulus "came from the direct self-interest of particular dominant groups.

${ }^{16}$ Boston: Beacon Press, 1944, p. 71. The historical claims are backed up in Polanyi et al., eds., Trade and Markets in the Early Empires (Glencoe, Ill.: Free Press, 1957).

${ }^{17}$ Charles P. Kindleberger, The World in Depression, 1929-1939 (Berkeley: University of California Press, 1973), esp. chaps. 1 and 14.

${ }^{18}$ "The Rise of Free Trade in Western Europe, 1820-1875," Journal of Economic History 35 (March 1975): 20-55. 
"19 In the Netherlands, these were merchants, shipowners, and bankers; in Great Britain, the manufacturing sectors backed by the intellectual hegemony established by the Manchester School; in France, largely industrial interests employing imported materials and equipment in production, though they would not have succeeded against the weight of countervailing interests had not Louis Napoleon imposed free trade for unrelated reasons of international diplomacy; in Prussia, grain and timber exporters, though Bismarck was not adverse to using trade treaties in the pursuit of broader objectives and free trade treaties seemed to be au courant; in Italy, the efforts of Cavour, which prevailed over disorganized opposition. Equally particularistic factors were at work in Belgium, Denmark, Norway, Sweden, Spain, and Portugal. But how did such diverse forces come to converge on the single policy response of free trade? In a certain sense, Kindleberger contends, Europe in this period should be viewed not as a collection of separate economies, but "as a single entity which moved to free trade for ideological or perhaps better doctrinal reasons." ${ }^{20}$ The image of the market became an increasingly captivating social metaphor and served to focus diverse responses on the outcome of free trade. And unless one holds that ideology and doctrine exist in a social vacuum, this ascendancy of market rationality in turn must be related to the political and cultural ascendance of the middle classes. In Polanyi's inimitable phrase, "Laissez-faire was planned. . .."21

In sum, this shift in what we might call the balance between "authority" and "market" fundamentally transformed state-society relations, by redefining the legitimate social purposes in pursuit of which state power was expected to be employed in the domestic economy. The role of the state became to institute and safeguard the self-regulating market. To be sure, this shift occurred unequally throughout western Europe, and at uneven tempos. And of course nowhere did it take hold so deeply and for so long a period as in Great Britain. Great Britain's supremacy in the world economy had much to do with the global expansion of this new economic order, and even more with its stability and longevity. But the authority relations that were instituted in the international regimes for money and trade reflected a new balance of state-society relations that expressed a collective reality.

These expectations about the proper scope of political authority in economic relations did not survive World War I. Despite attempts at restoration, by the end of the interwar period there remained little doubt about how thoroughly they had eroded. Polanyi looked back over the period of the "twenty years' crisis" from the vantage point of the Second World War-at the emergence of mass movements from the Left and the Right throughout Europe, the revolutionary and counterrevolutionary upheavals in central

${ }^{19}$ Ibid., p. 50.

${ }^{20}$ Ibid., p. 51, italics added.

${ }^{21}$ Polanyi describes the parallel movements, in the case of Great Britain, of the middle class into the political arena and the state out of the economic arena. 
and eastern Europe in the 1917-20 period, the General Strike of 1926 in Great Britain, and, above all, the rapid succession of the abandonment of the gold standard by Britain, the instituting of the Five Year Plans in the Soviet Union, the launching of the New Deal in the United States, unorthodox budgetary policies in Sweden, corporativismo in Fascist Italy, and Wirkschaftslenkung followed by the creation of both domestic and international variants of the "new economic order" by the Nazis in Germany. Running throughout these otherwise diverse events and developments, he saw the common thread of social reaction against market rationality. Statesociety relations again had undergone a profound-indeed, the greattransformation, as land, labor, and capital had all seized upon the state in the attempt to reimpose broader and more direct social control over market forces. Once this domestic transformation began, late in the 19th century, international liberalism of the orthodox kind was doomed. Thus, it was the singular tragedy of the interwar period, Polanyi felt, to have attempted to restore internationally, in the form of the gold-exchange standard in particular, that which no longer had a corresponding social base domestically. The new international economic order that would emerge from World War II, Polanyi concluded, on the one hand would mark the end of "capitalist internationalism," as governments learned the lesson that international automaticity stands in fundamental and potentially explosive contradiction to an active state domestically, and, on the other hand, the emergence of deliberate management of international economic transactions by means of collaboration among governments. ${ }^{22}$

Some of Polanyi's thoughts about the future had already been entertained by the individuals who would come to be directly responsible for negotiating the monetary component of the postwar international economic order. In the depth of the Depression, Harry Dexter White had pondered the problem of how to buffer national economies from external disturbances without, at the same time, sacrificing the benefits of international economic relations. "The path, I suspect, may lie in the direction of centralized control over foreign exchanges and trade." ${ }^{23}$ Indeed, in 1934 White had applied for a fellowship to study planning techniques at the Institute of Economic Investigations of Gosplan in Moscow. Instead, he accepted an offer to go to Washington and work in the New Deal. For his part, one of the first assignments that Keynes undertook after he joined the British Treasury in 1940 was to draft the text of a radio broadcast designed to discredit recent propaganda proclamations by Walther Funk, minister for economic affairs and president of the Reichsbank in Berlin, on the economic and social benefits that the "New Order" would bring to Europe and the world. Keynes was instructed to stress the traditional virtues of free trade and the gold standard. But this, he felt, "will not have much propaganda value." Britain would have to offer

${ }^{22}$ The Great Transformation, esp. chaps. 2 and 19-21.

${ }^{23}$ Quoted in Van Dormael, Bretton Woods, p. 41. 
"the same as what Dr. Funk offers, except that we shall do it better and more honestly." ${ }_{24} \mathrm{He}$ had reached the conclusion that only a refinement and improvement of the Schachtian device would restore equilibrium after the war. "To suppose that there exists some smoothly functioning automatic mechanism of adjustment which preserves equilibrium if only we trust to methods of laissez-faire is a doctrinaire delusion which disregards the lessons of historical experience without having behind it the support of sound theory." 25

Polanyi's prediction of the end of capitalist internationalism does not stand up well against the subsequent internationalization of production and finance; White's views were altered considerably over the years as a result of negotiations within the bureaucracy and the adversarial process with Congress, before he was driven from Washington altogether in an anticommunist witch-hunt; and American resistance scaled down even the multilateral variants of Keynes's ambitious vision. Yet each had been correct in the essential fact that a new threshold had been crossed in the balance between "market" and "authority," with governments assuming much more direct responsibility for domestic social security and economic stability. The extension of the suffrage and the emergence of working-class political constituencies, parties, and even governments was responsible in part; but demands for social protection were very nearly universal, coming from all sides of the political spectrum and from all ranks of the social hierarchy (with the possible exception of orthodox financial circles). Polanyi, White, and Keynes were also correct in their premise that, somehow, the postwar international economic order would have to reflect this change in state-society relations if the calamities of the interwar period were not to recur.

\section{Transformations in power versus purpose}

Changes in the distribution of power and in the structure of social purpose covaried from the pre-World War I era through to the interwar period, so that we cannot say with any degree of certainty what might have happened had only one changed. However, by looking at the relationship between the two in greater detail in a single, circumscribed domain, we may get closer to a firm answer. I focus on the monetary regime under the gold standard before World War I, and its attempted approximation in the goldexchange standard of the interwar period.

I begin with the domestic side of things, though this distinction itself would barely apply to currencies under a "gold specie" standard ${ }^{26}$ where

${ }^{24}$ Quoted in ibid., p. 7.

${ }^{25}$ Quoted in ibid., p. 32.

${ }^{28}$ Unless otherwise noted, this paragraph is based on League of Nations [Ragnar Nurkse], International Currency Experience: Lessons of the Inter-War Period (League of Nations, Economic, Financial and Transit Department, 1944), chap. 4. (Hereafter referred to as Nurkse.) 
both domestic circulation and international means of settlement took the form largely of gold, and the domestic money supply therefore was determined directly and immediately by the balance of payments. Under the more familiar "gold bullion" standard prior to World War I, where the bulk of domestic money took the form of bank notes and deposits, backed by and fixed in value in terms of gold, there still existed a strong relationship between domestic money supply and the balance of payments, but it was more indirect. In theory, it worked via the effects of gold movements on the domestic credit supply: an expansion of credit in the gold-receiving country, and a contraction in the gold-losing country, affected prices and incomes in such a way as to close the balance of payments discrepancy that had triggered the gold movement in the first place. This was reinforced by an attending change in money rates, which would set off equilibrating movements in short-term private funds. In practice, gold movements among the major economies were relatively infrequent and small. Temporary gaps to a large extent were filled by short-term capital movements, responding to interest differentials or slight variations within the gold points. ${ }^{27}$ More fundamental adjustments were produced by the impact of the balance of payments not only on domestic money stock and the volume of credit, but also through the direct effects of export earnings on domestic income and effective demand.

In sum, even in its less than pristine form, the pre-World War I gold standard was predicated upon particular assumptions concerning the fundamental purpose of domestic monetary policy and the role of the state in the process of adjusting imbalances in the level of external and internal economic activity. With respect to the first, in Bloomfield's words, the "dominant and overriding" objective of monetary policy was the maintenance of gold parity. "The view, so widely recognized and accepted in recent decades, of central banking policy as a means of facilitating the achievement and maintenance of reasonable stability in the level of economic activity and prices was scarcely thought about before 1914, and certainly not accepted, as a formal objective of policy." 28 Second, insofar as the adjustment process ultimately was geared to securing external stability, state abstinence was prescribed so as not to undermine the equilibrating linkages between the balance of payments, changes in gold reserves and in domestic credit supply,

\footnotetext{
${ }^{27}$ Note, however, Bloomfield's cautionary remark: "While this picture is broadly accurate, the nature and role of private short-term capital movements before 1914 have usually been oversimplified and their degree of sensitivity to interest rates and exchange rates exaggerated. At the same time these movements have been endowed with a benign character that they did not always possess." Arthur I. Bloomfield, "Short-Term Capital Movements Under the Pre-1914 Gold Standard," Princeton Studies in International Finance 11 (1963), p. 34. Bloomfield presents a more complex and balanced picture, which, however, does not contradict the basic generalization.

${ }^{28}$ Arthur I. Bloomfield, Monetary Policy Under the International Gold Standard (New York: Federal Reserve Bank of New York, 1959), p. 23. Bloomfield shows that central banks did attempt partially to "sterilize" the effects of gold flows.
} 
income, and demand. This was not incompatible with partial efforts at sterilization. As Nurkse put it, "all that was required for this purpose was that countries should not attempt to control their national income and outlay by deliberate measures-a requirement which in the age of laissez-faire was generally fulfilled." 29

It is impossible to say precisely when these assumptions ceased to be operative and their contraries took hold. But it is clear that after World War I there was a growing tendency "to make international monetary policy conform to domestic social and economic policy and not the other way round." 30 The proportion of currency reserves held in the form of foreign exchange more than doubled between 1913 and 1925, to 27 percent; in 1928, it stood at $\mathbf{4 2}$ percent. And international reserves increasingly came to serve as a "buffer" against external economic forces rather than as their "transmitter"; Nurkse found that throughout the interwar period the international and domestic assets of central banks moved in opposite directions far more often than in the same direction. ${ }^{31}$ After the collapse of the gold-exchange standard in 1931, exchange stabilization funds were established in the attempt to provide more of a cushion than "neutralization" had afforded. Mere stabilization was followed by direct exchange controls in many instances, with the gold bloc countries attempting to achieve analogous insulation through import quotas. Governments everywhere had developed increasingly active forms of intervention in the domestic economy in order to affect the level of prices and employment, and to protect them against external sources of dislocation. ${ }^{32}$ The international monetary order disintegrated into five more or less distinct blocs, each with its own prevailing currency arrangement.

On the international side, there is little doubt that the pre-World War I gold standard functioned as it did because of the central part Great Britain played in it. In general terms, "if keeping a free market for imports, maintaining a flow of investment capital, and acting as lender of last resort are the marks of an 'underwriter' of an international system, then Britain certainly fulfilled this role in the nineteenth-century international economy." 33 More specifically, in the domain of monetary policy it was the role of sterling as the major vehicle currency, held by foreign business, banks, and even central banks, that gave the Bank of England the influence to shape international monetary conditions consistent with the fundamental commitments and

\footnotetext{
${ }^{29}$ Nurkse, International Currency Experience, p. 213.

${ }^{30}$ Ibid., p. 230.

${ }^{31}$ Ibid., pp. 68-88.

${ }^{32}$ For a good global overview of these policy shifts, see Asa Briggs, "The World Economy: Interdependence and Planning," in C. L. Mowat, ed., The New Cambridge Modern History, vol. 12 (Cambridge: Cambridge University Press, 1968).

${ }^{33}$ Robert J. A. Skidelsky, "Retreat from Leadership: The Evolution of British Economic Foreign Policy, 1870-1939," in Benjamin M. Rowland, ed., Balance of Power or Hegemony: The Interwar Monetary System (New York: New York University Press, 1976), p. 163. Cf. Kindleberger, The World in Depression, chap. 1.
} 
dynamics of the regime. And yet, the critical issue in the stability of this regime was not simply some measure of material "supremacy" on the part of Britain, but that "national monetary authorities were inclined to 'follow the market' - and indirectly the Bank of England-rather than to assert independent national objectives of their own." ${ }^{34}$ Thus, the international gold standard rested on both the special position of Great Britain and prevailing attitudes concerning the role of the state in the conduct of national monetary policy. It reflected a true "hegemony," as Gramsci used the term.

What of the interwar period? Counterfactual historiography is little better than a parlor game under ideal circumstances; it should be especially suspect when an outcome is as overdetermined as institutional failure in the international economy between the wars ${ }^{35}$ It seems reasonable to assume, though, that with the end of monetary laissez-faire, "the monetary leader would need to dispose of more monetary influence and political authority than Britain ever possessed, except within its own imperial system." ${ }^{36}$ And where British hegemony lingered on, as in the Financial Committee of the League of Nations, the outcome was not salutary. For example, the eastern European countries that had their currencies stabilized by the League and were put under the gold-exchange standard before the major countries had fixed their currency rates did so at considerable domestic social cost ${ }^{37}$ And virtually every effort at constructing a viable international monetary regime in the interwar period, in which Britain took a leading role, did little more than decry the newly prevailing social objectives of state policy while pleading for a speedy return to the principles of "sound finance." 38 The consequences of course were counterproductive: just as the rhetoric of the

${ }^{34}$ Harold van B. Cleveland, "The International Monetary System in the Interwar Period," in Rowland, Balance of Power, p. 57, emphasis added. Note, in addition, that major primaryproducing countries, who may well have borne more than their share of the international adjustment process under the gold standard, by and large did not establish their own central banks until the 1930s - this includes Argentina, Canada, India, New Zealand, and Venezuela. The argument that the adjustment process worked disproportionately on primary-producing countries is made by Robert Triffin, "National Central Banking and the International Economy," in Lloyd A. Metzler et al., eds., International Monetary Policies (Washington, D.C.: Board of Governors of the Federal Reserve System, 1947).

${ }^{35}$ There is almost no end to the number of dislocating features of the post-World War I international economy that can be adduced as part of the explanation for its institutional failure. Kindleberger, The World in Depression, chap. 1, briefly recounts most of them.

${ }^{36}$ Cleveland, "International Monetary System," p. 57.

${ }^{37}$ "'The deflationist's ideal came to be 'a free economy under a strong government'; but while the phrase on government meant what it said, namely, emergency powers and suspension of public liberties, 'free economy' meant in practice the opposite of what it said: . . . while the inflationary governments condemned by Geneva subordinated the stability of the currency to stability of incomes and employment, the deflationary governments put in power by Geneva used no fewer interventions in order to subordinate the stability of incomes and employment to the stability of the currency." Polanyi, The Great Transformation, p. 233. For French skepticism concerning the "dogma of Geneva," see Judith L. Kooker, "French Financial Diplomacy: The Interwar Years," in Rowland, Balance of Power.

${ }^{38}$ For summary descriptions of the major conferences, see Dean E. Traynor, International Monetary and Financial Conferences in the Interwar Period (Washington, D.C.: Catholic Universities Press of America, 1949). 
League concerning collective security and disarmament sought and in some measure served morally to undermine the balance of power system, without providing a viable alternative, so too did the League and successive international gatherings in the monetary sphere seek to undermine the legitimacy of domestic stabilization policies while offering only the unacceptable goldexchange standard in their place. ${ }^{39}$

It is hardly surprising, therefore, that apart from Britain, seized by its own ideology and institutional past and willing to pay the domestic social cost, there were few takers among the major countries.$^{40}$ In sum, efforts to construct international economic regimes in the interwar period failed not because of the lack of a hegemon. They failed because, even had there been a hegemon, they stood in contradiction to the transformation in the mediating role of the state between market and society, which altered fundamentally the social purpose of domestic and international authority. As Ragnar Nurkse observed in 1944,

There was a growing tendency during the inter-war period to make international monetary policy conform to domestic social and economic policy and not the other way round. Yet the world was still economically interdependent; and an international currency mechanism for the multilateral exchange of goods and services, instead of primitive bilateral barter, was still a fundamental necessity for the great majority of countries. The problem was to find a system of international currency relations compatible with the requirements of domestic stability. Had the period been more than a truce between two world wars, the solution that would have evolved would no doubt have been in the nature of a compromise. ${ }^{41}$

Ultimately, it was. The liberalism that was restored after World War II differed in kind from that which had been known previously. My term for it is "embedded liberalism."

${ }^{39}$ The most trenchant critique of the moral failure of the League remains that of Edward Hallett Carr, The Twenty Years' Crisis, 1919-1939 (1939, 1946; New York: Harper Torchbooks, 1964).

${ }^{40}$ For example, France decided in 1928 to accept only gold in settlement of the enormous surplus it was accruing; and in 1929 the U.S. "went off on a restrictive monetary frolic of its own" even though it was in surplus" (Cleveland, "International Monetary System," p. 6). Four years later, in his inaugural address, President Roosevelt proclaimed the primacy of domestic stabilization, as he did again a few months later when, on the eve of the World Economic Conference of 1933, he took the U.S. off gold.

${ }^{41}$ International Currency Experience, p. 230. Note that Nurkse was speaking of "the great majority of countries." Those who chose bilateralism as an instrument of economic warfare and imperialism were unlikely to be accommodated within any multilateral regime. However, mere state trading or even the participation of centrally planned economies, while posing special problems, were not seen to be insuperable obstacles to multilateralism; see Herbert Feis, "The Conflict Over Trade Ideologies," Foreign Affairs 25 (July 1947), and Raymond F. Mikesell, "The Role of the International Monetary Agreements in a World of Planned Economies," Journal of Political Economy 55 (December 1947). I think it is fair to say, though, that reconciling the many variants and depths of state intervention would have been a difficult task in the best of times, which the 1930s of course weren't. We are justified, therefore, in "coding" the interwar period as "no hegemon, no agreement on purpose." 


\section{The compromise of embedded liberalism}

Liberal internationalist orthodoxy, most prominent in New York financial circles, proposed to reform the old order simply by shifting its locus from the pound to the dollar and by ending discriminatory trade and exchange practices. ${ }^{42}$ Opposition to economic liberalism, nearly universal outside the United States, differed in substance and intensity depending upon whether it came from the Left, Right, or Center, but was united in its rejection of unimpeded multilateralism. ${ }^{43}$ The task of postwar institutional reconstruction, as Nurkse sensed, was to maneuver between these two extremes and to devise a framework which would safeguard and even aid the quest for domestic stability without, at the same time, triggering the mutually destructive external consequences that had plagued the interwar period. This was the essence of the embedded liberalism compromise: unlike the economic nationalism of the thirties, it would be multilateral in character; unlike the liberalism of the gold standard and free trade, its multilateralism would be predicated upon domestic interventionism.

If this was the objective of postwar institutional reconstruction for the international economy, there remained enormous differences among countries over precisely what it meant and what sorts of policies and institutional arrangements, domestic and international, the objective necessitated or was compatible with. This was the stuff of the negotiations on the postwar international economic order. The story of these negotiations has been told by others, in detail and very ably. ${ }^{44} \mathrm{I}$ make no attempt to repeat it here. I simply summarize the conjunction of the two themes that constitutes the story's plot. The first, which we tend to remember more vividly today, concerned

${ }^{42}$ Professor John H. Williams, vice-president of the Federal Reserve Bank of New York, was a leading spokesman for the New York financial community, which resented having lost control over international monetary affairs when authority shifted from the FRBNY to the U.S. Treasury under Secretary Morgenthau. Their plan, which had some support in Congress, called simply for a resurrection of the gold-exchange standard, with the dollar performing the role that sterling had played previously. They opposed the New Deal "gimmickry" of the White Plan, and of course they liked Keynes's Clearing Union even less. See Van Dormael, Bretton Woods, chap. 9.

${ }^{43}$ In the case of Britain, the other major actor in the negotiations concerning postwar economic arrangements, opposition from the Left was based on the desire to systematize national economic planning, which would necessarily entail discriminatory instruments for foreign economic policy. Opposition from the Right stemmed from a commitment to imperial preferences and the imperial alternative to a universal economic order. Speaking for many moderates, Hubert Henderson was opposed because he doubted the viability of a "freely working economic system," that is, of laissez-faire. "To attempt this would be not to learn from experience but to fly in its face. It would be to repeat the mistakes made last time in the name of avoiding them. It would be to invite the same failure, and the same disillusionment; the same economic chaos and the same shock to social and political stability; the same discredit for the international idea." (Richard N. Gardner, Sterling-Dollar Diplomacy in Current Perspective [New York: Columbia University Press, 1980], chap. 1; the quotation is from a memorandum prepared by Henderson in December 1943, while serving in the British Treasury; reproduced in Gardner, p. 30.)

14 The following account draws heavily on Gardner's classic study, as supplemented by the greater detail on the monetary side presented in Van Dormael. 
multilateralism versus discrimination. It was an achievement of historic proportions for the United States to win adherence to the principle of multilateralism, particularly in trade. It required the expenditure of enormous resources. Still, it would not have succeeded but for an acceptable resolution of the dilemma between internal and external stability, the story's second theme. Here, history seemed not to require any special agent. True, the United States from the start of the negotiations was far less "Keynesian" in its positions than Great Britain. Within the United States, the social and economic reforms of the New Deal had lacked ideological consistency and programmatic coherence, and opposition had remained firmly entrenched. The transformation of the full-employment bill into the Employment Act of 1946 demonstrated the country's continuing ambivalence toward state intervention. This, of course, affected the outcome of the negotiations. Indeed, the United States would come to use its influence abroad in the immediate postwar years, through the Marshall Plan, the Occupation Authorities in Germany and Japan, and its access to transnational labor organizations, for example, to shape outcomes much more directly, by seeking to moderate the structure and political direction of labor movements, to encourage the exclusion of Communist Parties from participation in governments, and generally to discourage collectivist arrangements where possible or at least contain them within acceptable Center-Left bounds. ${ }^{45}$ But these differences among the industrialized countries concerned the forms and depth of state intervention to secure domestic stability, not the legitimacy of the objective. ${ }^{46}$

In the event, on the list of Anglo-American postwar economic objectives, multilateralism was joined by collaboration to assure domestic economic growth and social security as early as the Atlantic Charter, issued in August 1941. Indeed, progress on multilateralism seemed to be made contingent upon progress in expanding domestic production, employment, and the exchange and consumption of goods in Article VII of the Mutual Aid Agreement (Lend Lease), which was signed in February 1942.

On the monetary side, however different White's Stabilization Fund may have been from Keynes's Clearing Union (and there were considerable differences on instrumentalities), they shared a common purpose: intergov-

${ }^{45}$ Charles S. Maier, "The Politics of Productivity: Foundations of American International Economic Policy After World War II," International Organization 31 (Autumn 1977), and Robert W. Cox, "Labor and Hegemony," International Organization 31 (Summer 1977).

${ }^{46}$ Interesting in this regard is the role played by Leon Keyserling, appointed in 1949 as the first Keynesian on the Council of Economic Advisers, in helping to undermine the previous "economy-in-defense" policy by providing economic support for the proposed rearmament program contained in NSC-68 (Fred M. Kaplan, "Our Cold-War Policy, Circa '50," New York Times Magazine, 18 May 1980). Radicals have implied that "military Keynesianism" was the only kind of Keynesianism acceptable in the U.S. at that time (cf. Fred L. Block, The Origins of International Economic Disorder [Berkeley: University of California Press, 1977], pp. 102-8). But this interpretation slights the substantial state involvement in the U.S. in the postwar years in infrastructural investment (interstate highways, for example), agricultural price supports, and even in social expenditures, well before the full impact of Keynesian thinking was felt on monetary and fiscal policy in the 1960 s. 
ernmental collaboration to facilitate balance-of-payments equilibrium, in an international environment of multilateralism and a domestic context of full employment. Early in 1943, Adolf Berle foresaw that the compromise on the means to achieve these ends would have to "free the British people from their fear that they might have to subordinate their internal social policy to external financial policy, and to assure the United States that a share of its production was not claimable by tender of a new, 'trick' currency, and that the economic power represented by the US gold reserves would not be substantially diminished." 47 By the time of the Anglo-American "Joint Statement of Principles," issued not long before the Bretton Woods Conference, the consensus that had emerged provided for free and stable exchanges, on the one hand, and, on the other, the erection of a "double screen," in Cooper's words, ${ }^{48}$ to cushion the domestic economy against the strictures of the balance of payments. Free exchanges would be assured by the abolition of all forms of exchange controls and restrictions on current transactions. Stable exchanges would be secured by setting and maintaining official par values, expressed in terms of gold. The "double screen" would consist of short-term assistance to finance payments deficits on current account, provided by an International Monetary Fund, and, so as to correct "fundamental disequilibrium," the ability to change exchange rates with Fund concurrence. Governments would be permitted to maintain capital controls.

In devising the instruments of the monetary regime, the most intense negotiations were occasioned by the functioning of the "double screen." On the question of the Fund, Keynes had argued for an international overdraft facility. This would have created some $\$ 25$ billion to $\$ 30$ billion in new liquidity, with the overall balance of credits and debits in the Fund being expressed in an international unit of account, which was to be monetized. The arrangement would have been self-clearing unless a country were out of balance with the system as a whole, in which case corrective measures were called for on the part of creditors and debtors alike. The White plan originally called for a $\$ 5$ billion Fund, though the U.S. ultimately agreed to $\$ 8.8$ billion. However, these funds would have to be paid in by subscription. Access to the Fund as well as total liability were strictly limited by quotas, which in turn reflected paid-in subscriptions-the initial U.S. contribution was $\$ 3.175$ billion. And a country that sought to draw on the Fund had to make "representations" that the particular currency was needed for making payments on current account. Thus, with the United States, the sole major creditor country, seeking to limit its liabilities, the first part of the "double screen" was both more modest and more rigid than the United Kingdom and other potential debtor countries would have liked. But there was no question about its being provided. On the second part, exchange rate changes, the

${ }^{47}$ Paraphrased by Van Dormael, Bretton Woods, p. 103.

${ }^{48}$ Richard N. Cooper, "Prolegomena to the Choice of an International Monetary System," International Organization 29 (Winter 1975), p. 85. 
U.K. was more successful in assuring automaticity and limiting intrusions into the domain of domestic policy. The Fund was required to concur in any change necessary to correct a "fundamental disequilibrium," and if the change was less than 10 percent the Fund was given no power even to raise objections. Most important, the Fund could not oppose any exchange rate change on the grounds that the domestic social or political policies of the country requesting the change had led to the disequilibrium that made the change necessary. Lastly, the final agreement did include a provision to shift at least some of the burden of adjustment onto creditor countries. This was by means of the "scarce currency" clause, which Keynes, in the end, thought to be quite important. It empowered the Fund, by decision of the Executive Directors, to ration its supply of any currency that had become scarce in the Fund and authorized members to impose exchange restrictions on that currency.

Once negotiations on postwar commercial arrangements got under way seriously, in the context of preparations for an International Conference on Trade and Employment, the principles of multilateralism and tariff reductions were affirmed, but so were safeguards, exemptions, exceptions, and restrictions-all designed to protect the balance of payments and a variety of domestic social policies. The U.S. found some of these abhorrent and sought to limit them, but even on so extraordinary an issue as making full employment an international obligation of governments it could do no better than to gain a compromise. The U.S. Senate subsequently refused to ratify the Charter of the International Trade Organization (ITO), as a result of which a far smaller domain of commercial relations became subject to the authority of an international regime than would have been the case otherwise. The regulation of commodity markets, restrictive business practices, and international investments were the most important areas thereby excluded. ${ }^{49}$ But within this smaller domain, consisting of the more traditional subjects of commercial policy, the conjunction of multilateralism and safeguarding domestic stability that had evolved over the course of the ITO negotiations remained intact. ${ }^{50}$

Jacob Viner summarized the prevailing consensus in 1947, at the time of the negotiations for a General Agreement on Tariffs and Trade (GATT): "There are few free traders in the present-day world, no one pays any attention to their views, and no person in authority anywhere advocates free trade." 51 The United States, particularly the State Department, was the

${ }^{49}$ The provisions of the ITO Charter became internally so inconsistent that it is difficult to say just what sort of a regime it would have given rise to. See William Diebold Jr., "The End of the ITO," Princeton Essays in International Finance 16 (Princeton, N.J., October 1952).

${ }^{30}$ The following account draws heavily on Gardner, Sterling-Dollar Diplomacy, and on Gerard and Victoria Curzon, "The Management of Trade Relations in the GATT," in Andrew Shonfield, ed., International Economic Relations of the Western World, 1959-1971, vol. I (London: Oxford University Press for the Royal Institute of International Affairs, 1976).

${ }^{31}$ Jacob Viner, "Conflicts of Principle in Drafting a Trade Charter," Foreign Affairs 25 (January 1947), p. 613. 
prime mover behind multilateralism in trade. But this meant nondiscrimination above all. The reduction of barriers to trade of course also played a role in American thinking, but here too the concern was more with barriers that were difficult to apply in a nondiscriminatory manner. Tariff reduction was subject to much greater domestic constraint. For their part, the British made it clear from the beginning that they would countenance no dismantling of imperial preferences unless the U.S. agreed to deep and linear tariff cuts. The proposed Commercial Union, put forward by James Meade on behalf of Britain, contained such a formula, together with an intergovernmental code of conduct for trade and machinery to safeguard the balance of payments. But the U.S. Congress could not be expected to accept linear tariff cuts. ${ }^{52}$

The General Agreement on Tariffs and Trade made obligatory the most-favored-nation rule, but a blanket exception was allowed for all existing preferential arrangements, and countries were permitted to form customs unions and free trade areas. Moreover, quantitative restrictions were prohibited, but were deemed suitable measures for safeguarding the balance of payments-explicitly including payments difficulties that resulted from domestic policies designed to secure full employment. They could also be invoked in agricultural trade if they were used in conjunction with a domestic price support program. The substantial reduction of tariffs and other barriers to trade was called for; but it was not made obligatory and it was coupled with appropriate emergency actions, which were allowed if a domestic producer was threatened with injury from import competition that was due to past tariff concessions. The Agreement also offered a blanket escape from any of its obligations, provided that two-thirds of the contracting parties approved. Lastly, procedures were provided to settle disputes arising under the Agreement and for the multilateral surveillance of the invocation of most (though not all) of its escape clauses. The principle of reciprocity was enshrined as a code of conduct, to guide both tariff reductions and the determination of compensation for injuries suffered.

To repeat my central point: that a multilateral order gained acceptance reflected the extraordinary power and perseverance of the United States. ${ }^{53}$

\footnotetext{
${ }^{32}$ In the spring of 1947 , the U.S. delegation arrived in Geneva armed with congressional authorization for an overall tariff reduction to $50 \%$ of their 1945 levels (which, however, would still have left U.S. tariffs relatively high), in return for elimination of preferences. But, at the same time, the United States entered into preferential trade agreements with Cuba and the Philippines. Though mutual concessions on several important items were made in Geneva, in the end some $70 \%$ of existing British preferences remained intact (Gardner, Sterling-Dollar Diplomacy, chap. 17).

${ }^{53}$ At the Palm Springs Conference, Peter Kenen argued that this is true more for trade than for money. He maintains that, with the exception of the particulars of the credit arrangement (and the future role of the dollar, which I take up below), the general outlines of Bretton Woods would not have differed appreciably had there not been an American hegemon present. This is so because the basic design rested on a widely shared consensus. However, in trade, Kenen suggests, it is unlikely that nondiscrimination would have been accepted as a guiding principle had it not been for American "muscle." Keep in mind that even here the U.S. was forced to accept the indefinite continuation of all existing preferential trade agreements.
} 
But that multilateralism and the quest for domestic stability were coupled and even conditioned by one another reflected the shared legitimacy of a set of social objectives to which the industrial world had moved, unevenly but "as a single entity." Therefore, the common tendency to view the postwar regimes as liberal regimes, but with lots of cheating taking place on the domestic side, fails to capture the full complexity of the embedded liberalism compromise. ${ }^{54}$

\section{Complementary transaction flows}

The postwar regimes for trade and money got off to a slow start. The early GATT rounds of tariff negotiations were modest in their effects. As a lending institution, the IMF remained dormant well into the 1950s. Meanwhile, bilateral currency arrangements in the late 1940s and early 1950 s became far more extensive than they had ever been in the 1930s, doubling to some four hundred between 1947 and $1954 .{ }^{55}$ But by the late 1950s, the Europeans had "the worst of their post-war problems behind them-and new ones had not yet come to take their place." Both Europe and the United States were poised "on the brink of a decade of phenomenal expansion which imperiously demanded wider markets through freer trade." 56 This in turn demanded the elimination of exchange restrictions on current account. Liberalization in trade and money soon followed.

Preoccupation with the fact of subsequent liberalization has tended to detract from consideration of its precise characteristics, at least on the part of political scientists. ${ }^{57}$ The questions that have dominated discussion concern the impact of liberalization on the expansion of international economic transactions, or the effects on both of U.S. hegemony (with a time lag), operating directly by means of the exercise of American state power or indi-

${ }^{54}$ The third panel of the Bretton Woods triptych was the World Bank, which to some extent may also be said to reflect this conjunction of objectives. True, the grandiose concept of an international bank to engage in countercyclical lending and to help stabilize raw materials prices, which both White and Keynes had entertained at one point, was shelved due to opposition on both sides of the Atlantic. Nevertheless, for the first time, international public responsibility was acknowledged for the provision of investment capital, supplementing the market mechanism. For Secretary Morgenthau's strong views on this subject, see Gardner, SterlingDollar Diplomacy, p. 76.

${ }^{35}$ Of the 1954 total, 235 existed in Europe. Margaret G. De Vries and J. Keith Horsefield, The IMF, 1945-1965, vol. 2 (Washington, D.C.: International Monetary Fund, 1969), chap. 14.

${ }^{36}$ Curzon and Curzon, "Management of Trade," pp. 149-50.

${ }^{57}$ A notable exception is Kenneth N. Waltz, "The Myth of National Interdependence," in Charles P. Kindleberger, ed., The International Corporation (Cambridge: MIT Press, 1970). However, Waltz considers the characteristics of an international division of labor at any given point in time to be a product solely of international polarity. And this, in turn, requires that he consider Great Britain in the 19th century to have been but one among several coequal members of a plural system. He concludes that the international division of labor in the present era has been less extensive in kind and degree than in the pre-World War I setting because of bipolarity today and multipolarity then. 
rectly through the internationalization of American capital. These of course are interesting questions, but they are not the questions that concern me here. Having argued that the postwar regimes for trade and money institutionalized the normative framework of embedded liberalism, I now examine whether and how this framework is reflected in the character of the international economic transactions that emerged when imminent expansion "imperiously" demanded liberalization.

I proceed by way of hypothesis. Imagine a world of governments seized by the compelling logic of David Ricardo; following a bout with mercantilism, this world is poised "on the brink" of liberalization. What kinds of international economic transactions are governments likely to encourage?

Under a system of perfectly free trade each country naturally devotes its capital and labour to such employments as are most beneficial to each. This pursuit of individual advantage is admirably connected with the universal good of the whole. By stimulating industry, by rewarding ingenuity, and by using most efficaciously the peculiar powers bestowed by nature, it distributes labour most effectively and most economically; while, by increasing the general mass of productions, it diffuses general benefit, and binds together, by one common tie of interest and intercourse, the universal society of nations throughout the civilised world. It is this principle which determines that wine shall be made in France and Portugal, that corn shall be grown in America and Poland, and that hardware and other goods shall be manufactured in England. ${ }^{58}$

In short, our governments are likely to encourage an international division of labor based on the functional differentiation of countries that reflects their comparative advantage. Trade among them therefore would be socially highly profitable.

Now imagine the same governments under similar circumstances, the only difference being that they are committed to embedded liberalism rather than to laissez-faire. What sorts of international economic transactions would we expect them to favor? The essence of embedded liberalism, it will be recalled, is to devise a form of multilateralism that is compatible with the requirements of domestic stability. Presumably, then, governments so committed would seek to encourage an international division of labor which, while multilateral in form and reflecting some notion of comparative advantage (and therefore gains from trade), also promised to minimize socially disruptive domestic adjustment costs as well as any national economic and political vulnerabilities that might accrue from international functional differentiation. They will measure collective welfare by the extent to which these objectives are achieved. However, as neoclassical trade theory defines the term, the overall social profitability of this division of labor will be lower than of the one produced by laissez-faire.

${ }^{58}$ David Ricardo, Works, ed. by Piero Sraffa (Cambridge: Cambridge University Press, 1955), 1:133-34. 
Let us return from the world of hypothesis and review briefly the character of postwar transaction flows. ${ }^{39}$

The great bulk of international economic transactions since the $1950 \mathrm{~s}$ shows very definite patterns of concentration. The growth in trade has exceeded the growth in world output, and the most rapidly growing sector of trade has been in manufactured products among the industrialized countries. Within this general category, some two-thirds of the increase in trade from 1955 to 1973 is accounted for by "intracontinental" trade, that is, trade within western Europe and within North America. ${ }^{60}$ What is more, it appears that trade in products originating in the same sector, or "intra-industry" trade, is growing far more rapidly than trade involving products of different sectors. ${ }^{61}$ This in turn reflects a secular decline of specialization in different sectors of manufacturing activity among the industrialized countries. ${ }^{62}$ Lastly, there is evidence to suggest that trade among related corporate parties, or "intrafirm" trade, accounts for an ever-larger portion of total world trade. ${ }^{63}$ On the financial side, international investments have been rising even more rapidly than world trade, and they conform roughly to the same pattern of geographical, sectoral, and institutional concentration. ${ }^{64}$ This is also true of international transfers of short-term funds. ${ }^{65}$

What kind of division of labor among the industrialized countries do these patterns portray? It is, in Cooper's words, one characterized by a

${ }^{39}$ The facts are well enough known, but not enough is made of them. For example, I find that much of what I have to say is implied in if not anticipated by the locus classicus of liberal interdependence theorists: Richard N. Cooper, The Economics of Interdependence (1968; New York: Columbia University Press, 1980). However, Cooper was concerned with telling a different story, so he chose not to take up issues and conclusions that, from the present vantage point, appear more scintillating. To cite but one illustration, Cooper demonstrates a converging cost structure among the industrialized countries. His major concern is to argue that this contributes to the increasing marginal price sensitivity of rapidly growing foreign trade-that is, to interdependence as he defines the term. In passing, he mentions another implication of this convergence, but one "which will not much concern us here." It is "that international trade becomes less valuable from the viewpoint of increasing economic welfare" (pp. 75-76). This striking departure from the textbook case for free trade, amidst an explosion in world trade, is left unexplored.

${ }^{60}$ Richard Blackhurst, Nicolas Marian, and Jan Tumlir, "Trade Liberalization, Protectionism and Interdependence," GATT Studies in International Trade 5 (November 1977), pp. 18-19.

${ }^{61}$ Ibid., pp. 10-11, 15-16; and Charles Lipson's article in this volume.

${ }^{62}$ Richard Cooper has traced this back to 1938 , and finds that ten of thirteen manufacturing sectors show declines in variation among countries, and none shows a sharp increase. Cooper, Economics of Interdependence, pp. 74-78. In a further refinement, Blackhurst, Marian, and Tumlir, "Trade Liberalization," add that the proportion of imports and exports consisting of intermediate manufactured goods, as opposed to goods destined for final use, is rising rapidly, particularly in the category of engineering products. This reflects, among other things, "the growth in intra-branch specialization, foreign processing and sub-contracting"' (pp. 15-16).

${ }^{63}$ Gerald K. Helleiner, "Transnational Corporations and Trade Structure: The Role of Intra-Firm Trade," in Herbert Giersch, ed., Intra-Industry Trade (Tübingen: J. C. B. Mohr, Paul Siebeck, 1979).

${ }^{64}$ For a historical overview, see John H. Dunning, Studies in International Investments (London: Allen \& Unwin, 1970).

${ }^{65}$ A recent survey may be found in Joan Edelman Spero, The Failure of the Franklin National Bank (New York: Columbia University Press, 1980), chap. 2. 
"narrowing of the economic basis" on which international transactions rest. ${ }^{66}$ By this he means that international economic transactions increasingly reflect the effects of marginal cost and price differentials of similar activities and products, rather than the mutual benefits of divergent investment, production, and export structures. Moreover, within this division of labor there is a critical shift in functional differentiation from the level of country and sector to the level of product and firm. And the economic gains from trade are correspondingly smaller. ${ }^{67}$

All of this stands in stark contrast to the half-century prior to 1914. Intercontinental trade was higher ${ }^{68}$ Intersectoral trade dominated ${ }^{69}$ Longterm capital movements favored capital-deficient areas, and were concentrated overwhelmingly in the social-overhead capital sector of the borrowing countries. ${ }^{70}$ Marginal cost and price differentials appear to have had only limited bearing on the pattern of trade and investment flows $;^{71}$ the requirements of international functional differentiation and, later, absorptive capacity, account for much more of the variance. ${ }^{72}$ Lastly, the large dif-

${ }^{66}$ Economics of Interdependence, p. 68.

${ }^{67}$ Ibid., p. 76. Cooper adds that both product differentiation and economies of scale may modify this conclusion, "but several of the countries under consideration have sufficiently large domestic markets to reap most benefits likely to flow from large scale production even without trade."

${ }^{68}$ A. G. Kenwood and A. L. Lougheed, The Growth of the International Economy, 18201960 (London: Allen \& Unwin, 1971), chap. 5.

${ }^{69}$ For example, in 1913 Great Britain imported $87 \%$ of the raw materials it consumed (excluding coal), and virtually as much of its foodstuffs. Moreover, the share of primary products in world trade from 1876-1913 remained steady at about $62 \%$, even though total world trade trebled. And right up to World War I, Germany, Great Britain's main industrial rival, remained a major source of supply of manufactured materials for Great Britain, including chemicals and dyestuffs. Kenwood and Lougheed, Growth of International Economy, chap. 5 , and Briggs, "World Economy," p. 43.

${ }^{70}$ During the fifty years preceding 1914, the Americas received $51 \%$ of British portfolio foreign investment (North America 34\%, South America 17\%); overall, some $69 \%$ of British portfolio foreign investment went into transportation, public utilities, and other public works; $12 \%$ into extractive industries; and only $4 \%$ into manufacturing. Matthew Simon, "The Pattern of New British Portfolio Foreign Investment, 1865-1914," in A. R. Hall, ed., The Export of Capital from Britain (London: Methuen, 1968), p. 23; cf. A. K. Cairncross, Home and Foreign Investment, 1870-1913 (Cambridge: Cambridge University Press, 1953). A broader survey of the various forms of investment from all sources may be found in Kenwood and Lougheed, Growth of International Economy, chap. 2.

"For trade, see ibid., chap. 5; for investment, A. I. Bloomfield, "Patterns of Fluctuations in International Investment Before 1914," Princeton Studies in International Finance 21 (1968), esp. pp. 35-40. Cooper (Economics of Interdependence, pp. 151-52), concerned to show that interdependence in the pre-1914 world economy "was something of an illusion," argues that despite the freedom of capital to move, "it did not in fact move in sufficient volume even to erase differences in short-term interest rates." (Emphasis added, to underscore his looking at the pre-1914 world through post-1960 lenses).

72 "The industrialization of Europe and the growth of its population created a steadily growing demand for raw materials and foodstuffs, much of which had to be imported. At the same time, important advances in technical knowledge, especially in transportation and communications, and the existence of underpopulated and land-rich countries in other continents provided the means whereby these demands could be met. The greater part of the foreign investment undertaken during the nineteenth century was concerned with promoting this international specialization between an industrial centre located in Europe (and, later, in the United States) and a 
ferences in comparative cost structures meant that trade was socially very profitable. ${ }^{73}$

To explain fully the differences between the pre-1914 and the post1950s international division of labor would require linking them to a number of potentially causal factors. Among these, the most frequently invoked are differences in the relative levels of economic and technological development of the major countries concerned $;{ }^{74}$ the evolution of the global organization of capital over the course of the past century; ${ }^{75}$ the effects of differences in the configuration of interstate power in the two eras ${ }^{76}$ and the respective external consequences of shifts in domestic state-society relations. ${ }^{77}$ International regimes thus do not determine these outcomes. At the same time, however, the close similarity between our hypothesized expectations of laissez-faire liberalism and embedded liberalism and actual patterns of transaction flows suggests that regimes do play a mediating role.

This mediating role of the postwar regimes for trade and money, and the complementary transaction flows to which they gave rise, have come to be recognized even by those most consistently espousing conventional liberal orthodoxies. As Charles Lipson points out, GATT negotiations have strongly favored intra-industry specialization. ${ }^{78}$ And a recent GATT study notes that liberalization has produced "surprisingly few adjustment problems" among the industrialized countries because there has been "no abandonment of whole industrial sectors." Instead, specialization is "achieved mainly by individual firms narrowing their product range. . . ."79 As a result, national export structures among the industrialized countries are becoming ever more alike. ${ }^{80}$ On reflection, however, this outcome should not cause surprise. For governments pursuing domestic stabilization, it is quite safe to liberalize this kind of trade. Adjustment costs are low. It poses none of the vulnerabilities that a true Ricardian specialization among sectors would pose. Whatever political vulnerabilities might arise from it are more or less shared by all parties to it, so that it is unlikely to lead to a contest for political

periphery of primary producing countries." Kenwood and Lougheed, Growth of International Economy, p. 48.

${ }^{73}$ Cooper, Economics of Interdependence, p. 152.

${ }^{74}$ This is generally considered to be the driving force by liberal economists, as exemplified by Cooper, ibid.

${ }^{75}$ Marxists have tended to stress this factor; see, for example, Christian Palloix, "The SelfExpansion of Capital on a World Scale," Review of Radical Political Economy 9 (Summer 1977), which is drawn from his larger work, L'internationalisation du capital (Paris: Maspero, 1975).

${ }^{76}$ This is the realists' explanandum, as developed in Waltz, "Myth of National Interdependence," though most realists, unlike Waltz, would characterize the distribution of power in the pre-1914 world political economy as having been hegemonic. Cf. Robert Gilpin, U.S. Power and the Multinational Corporation (New York: Basic Books, 1975).

${ }^{77}$ See Polanyi's Great Transformation for one expression of this social-organicist position; for another, from a different location on the political spectrum, see Gunnar Myrdal, Beyond the Welfare State (New Haven: Yale University Press, 1960).

${ }^{78} \mathrm{His}$ article in this volume.

${ }^{79}$ Blackhurst, Marian, and Tumlir, "Trade Liberalization," p. 11.

${ }^{80}$ See Lipson's article in this volume, and the references he cites. 
advantage among them. And all the while it offers gains from trade. In contrast, there has been no progress in liberalizing agricultural trade. Furthermore, where trade in industrial products is based on a more classical notion of comparative advantage, as it is with imports from the so-called newly industrializing countries, the trade regime has encountered difficulty. ${ }^{81}$ Apart from oil, North-South raw materials trade has posed few problems for the industrialized countries, both because of their overall domination of world trade and because of the characteristics of the raw materials sector. ${ }^{82}$

International financial flows may be expected to follow closely the evolving patterns of production and trade. Since the liberalization of payments facilities at the end of the 1950s and the loosening of capital controls in the early 1960s, they have done so. Two additional features of international financial transactions bear on my argument. First, international investments in social overhead capital, which provided the great bulk of private flows in the 1865-1914 period, now are almost the exclusive domain of national and international public institutions, acting alone or in cofinancing arrangements with private capital. ${ }^{83}$ This has meant a welcome supplement to the vagaries of the market mechanism for recipient countries, and for donor countries as well, though in a different sense. For the donor countries, it has meant an ability to exercise far greater discretion over patterns of investment decisions in this leading sector than governments in the 19th century either enjoyed or sought. Second, the international financial markets that emerged in the 1960s, above all the Euromarkets, offered governments an important supplement to the monetary regime. Under Keynes's Clearing Union, capital controls were combined with generous overdraft allowances and parity changes as needed. In their absence or, more accurately, under the more modest forms of each that came to prevail in the 1960s, these markets offered the prospect of an adjustment mechanism to cushion both surplus and deficit countries (at least in the short run). Accordingly, governments did little to control and much to encourage the formation and growth of these markets. ${ }^{84}$ Today, they constitute the main source of balance-of-payments financing. ${ }^{85}$

${ }^{81}$ This is not to suggest that the trade regime has encountered no other difficulties. One of the more serious is surplus capacity, which shows that the apparent ease with which liberalization has been accommodated was also dependent upon unprecedented rates of economic growth.

${ }^{82}$ Paul Bairoch, The Economic Development of the Third World since 1900 (Berkeley: University of California Press, 1975), chap. 5.

${ }^{83}$ Dunning, International Investments, chap. 1 . Governmental loans were largely confined to Continental Europe in the 19th century, and were small in comparison with private loans. Today, the situation is reversed in each respect.

${ }^{84} \mathrm{~A}$ good discussion of the role of governments in triggering the expansion of these markets may be found in Susan Strange, International Monetary Relations, vol. 2 of Shonfield, ed., International Economic Relations of the Western World, esp. chap. 6. Strange's primary concern is to show how the Euromarkets transformed from "good servant" to "bad master," by making difficult the conduct of domestic monetary policy and generally eroding national monetary sovereignty. The good servant role received rather more attention again in the mid to late 1970 s, following the enormous payments imbalances produced by oil price increases. More on this general problem below.

${ }^{85}$ Benjamin J. Cohen's article in this volume. 
In sum, international economic regimes do not determine international economic transactions. For determinants we have to look deeper into basic structural features of the world political economy. But, as we have seen, nor are international economic regimes irrelevant to international economic transactions. They play a mediating role, by providing a permissive environment for the emergence of certain kinds of transactions, specifically transactions that are perceived to be complementary to the normative frameworks of the regimes having a bearing on them. This conclusion does not imply that perceptions are never mistaken, that "good servants" never go on to become "bad masters," that complementarity is never condemned to coexist with contradiction-or, indeed, that international regimes have a bearing on the entire range of international transactions. Nor does it suggest that the effectiveness of international regimes may not become undermined by such disjunctions. The question of possible responses to second-order consequences of this sort takes us into a different analytical realm, that of regime change.

\section{Norm-governed change}

The 1970s witnessed important changes in central features of the postwar regimes for money and trade. Among political scientists and some economists, the decline of U.S. hegemony is most often adduced as the causa causans of these changes. Terms such as "erosion" and even "collapse" are most often invoked to describe them. Triffin depicted the Jamaica Accords as "slapstick comedy" rather than monetary reform, while for a former U.S. trade official the Tokyo Round "performed the coup de grace" on liberal trade. ${ }^{86}$ The sense of discontinuity is pervasive. Is it justified?

Once again I take temporary refuge in hypothesis. If we allow that international regimes are not simply emanations of the underlying distribution of interstate power, but represent a fusion of power and legitimate social purpose, our cause and effect reasoning becomes more complex. For then the decline of hegemony would not necessarily lead to the collapse of regimes, provided that shared purposes are held constant. Instead, one ought to find changes in the instrumentalities of regimes, which, under hegemony, are likely to have relied on disproportionate contributions by and therefore reflected the preferences of the hegemon. ${ }^{87}$ At the same time, one ought to find continuity in the normative frameworks of regimes, which would still

\footnotetext{
${ }^{86}$ Robert Triffin, "Jamaica: 'Major Revision' or Fiasco," in Edward M. Bernstein et al., "Reflections on Jamaica," Princeton Essays in International Finance 115 (Princeton, N.J., 1976), as cited in Benjamin J. Cohen, Organizing the World's Money (New York: Basic Books, 1977), chap. 4, fn. 24; and Thomas Graham, "Revolution in Trade Politics," Foreign Policy 36 (Fall 1979), p. 49.

${ }^{87}$ Supporters of the hegemonic stability position speak of "burdens of leadership"; critics, of "exorbitant privileges." The empirical referents are the same.
} 
reflect shared purposes. And the new instrumentalities ought to be more appropriate to the new power distribution while remaining compatible with the existing normative framework. In short, the result would be "normgoverned" change.

Let us turn back to the post-1971 changes in the regimes for money and trade. On the monetary side, the major changes at issue are the end of the dollar's convertibility into gold and the adoption of floating rates of exchange, both in violation of the original Articles of Agreement. On the trade side, no discrete event fully symbolizes the perceived discontinuities, though they are characterized generally as "the new protectionism" and include the proliferation of nontariff barriers to trade and violations of the principle of nondiscrimination, in the form of domestic interventions as well as internationally negotiated export restraints. In both cases a weakening of the central institutions, the IMF and the GATT, is taken to reflect the same syndrome.

It is my contention that, on balance, the hypothesis of norm-governed change accounts for more of the variance than claims of fundamental discontinuity.

\section{Base-line}

The base-line against which change is here to be compared consists of two parts. First, if we compare changes in the monetary and trade regimes against some ideal of orthodox liberalism, then we are bound to be disappointed if not shocked by recent trends. But we are also bound to be misled. For orthodox liberalism has not governed international economic relations at any time during the postwar period. My starting point, of course, is the institutional nexus of embedded liberalism. Within this framework, it will be recalled, multilateralism and domestic stability are linked to and conditioned by one another. Thus, movement toward greater openness in the international economy is likely to be coupled with measures designed to cushion the domestic economy from external disruptions. At the same time, measures adopted to effect such domestic cushioning should be commensurate with the degree of external disturbance and compatible with the long-term expansion of international transactions. Moreover, what constitutes a deviation from this base-line cannot be determined simply by the "objective" examination of individual acts in reference to specific texts. Rather, deviation will be determined by the "intersubjective" evaluation of the intentionality and consequences of acts within the broader normative framework and prevailing circumstances.

The second component of my base-line is the peculiar relation of the United States to the institutionalization of embedded liberalism immediately after the war. The United States. was, at one and the same time, the paramount economic power and the country in which the domestic state- 
society shift remained the most ambivalent. This had several complex consequences, with differential effects on the two regimes. The United States would have to provide the bulk of the material resources required to translate the negotiated compromises into institutional reality. This would give the U.S. influence that it could be expected to exercise in keeping not only with its own interests, but also with its preferred interpretations of both the compromises and how they were to be realized. The impact on the institutionalization of the trade agreement, once the ITO was abandoned, on the whole supported the basic design and need not detain us. But the institutionalization of the monetary agreement was profoundly skewed by the asymmetrical position of the U.S. ${ }^{88}$ At Bretton Woods, through a combination of stealth and inevitability, the dollar had become equated with gold and was recognized officially but apparently without the knowledge of Keynes as the key currency. ${ }^{89}$ Once the IMF came into existence, the U.S. insisted on terms of reference and a series of "interpretations" of the Articles, as well as decisions of the Executive Directors, that had the effect of launching what would come to be known as "IMF orthodoxy" and, inadvertently or otherwise, guaranteeing that there would be no intergovernmental alternative to U.S. payments deficits as the major instrument of international liquidity creation..$^{90}$ Thus, the monetary regime that emerged in the 1950 s already differed in several important respects from the intent of Bretton Woods.

It is against this starting point that subsequent developments must be assessed.

${ }^{88}$ The differential impact on the two regimes is explained largely by the total asymmetry that prevailed in the monetary domain and the relatively more balanced configuration in trade. In the case of money, the U.S. possessed the fungible resources that everyone required, including some two-thirds of the world's monetary gold supply, which it acquired as an unbalanced creditor country before World War II. At the same time, the U.S. saw no situation in which it might become dependent upon the regime as a debtor. The case of trade is inherently somewhat more symmetrical, since the mutual granting of access to markets is the key resource. It is also a domain in which the domestic constraints within the United States differed little from domestic constraints elsewhere.

${ }^{89}$ Harry Dexter White and his staff had complete control over the organization of meetings, scheduling of subjects, rules of procedure, and drafting of all official documentation including daily minutes and the Final Act. In addition, White headed the so-called special committee, which resolved ambiguities and elaborated operational details. According to Van Dormael, on whose account I draw here, this committee "prepared for inclusion in the Final Act a number of provisions that were never discussed nor even brought up" (Bretton Woods, pp. 2023). Even senior members of the American delegation were not always fully aware of what White was up to; Dean Acheson, normally no slouch, expressed confusion, and what he suspected he didn't much care for (ibid., pp. 200-203). In any case, Van Dormael attributes several features of the Fund to these organizational and procedural manipulations, the most important of which was an equation that no one else became aware of until after the fact, between gold and the U.S. dollar. This was in clear violation of the Joint Statement of Principles. Keynes had rejected any special role for the dollar; he favored the monetization of an international unit of account, and he assumed a multiple-currency reserve system. But in the final analysis, the major consequence of White's maneuverings on this issue was simply to give de jure expression to what surely would have occurred de facto and have been sanctified by subsequent practice.

${ }^{90}$ At the inaugural meeting of the Boards of Governors of the IMF and IBRD, held in Savannah, Georgia, the United States succeeded in having both institutions located in Washington, which could be expected to amplify day-to-day influence by Congress and the Administration, 
The post-1971 inconvertibility of the dollar into gold may be usefully framed within the broader rubric of liquidity problems and floating rates of exchange within adjustment problems. I take up each in turn, and conclude with a comment on the IMF.

As noted, the liquidity provisions of Bretton Woods proved inadequate, even though, as Cohen points out elsewhere in this volume, an adequate supply of international liquidity was one of its cardinal principles. The growing volume of international trade increased liquidity requirements, as did the growing magnitude of speculative pressure on exchange rates. The dollar exchange standard, which had "solved" this problem in the short run, was already in trouble when the monetary regime first began to function without the protective shield of the postwar transitional arrangements. In 1958 , just as the Europeans were resuming full convertibility of their currencies, U.S. gold reserves fell permanently below U.S. overseas liabilities. And before the next year was out, Professor Triffin had articulated his famous dilemma. ${ }^{91}$ Throughout the 1960 s, a seemingly endless series of stopgap measures was tried in an effort to devise what Robert Roosa, former

and in having the Executive Directors be full-time and highly paid officials, which was seen by the British as assuring greater Fund meddling in the affairs of members when they applied for assistance. They were not mistaken. In May 1947, the United States pushed through a meeting of the Executive Directors an "interpretation" of the Articles of Agreement, to the effect that the Fund could "challenge" the representations made by governments that a currency was presently needed for balance-of-payments purposes, and that the Fund had the authority to "postpone or reject the request, or accept it subject to conditions. . . ." (Reproduced in Horsefield, The IMF , 3:227, emphasis added.) This interpretation was confirmed by decision of the Executive Directors in 1948. And thus was IMF conditionality born. In a further decision, taken in 1952, conditionality was elaborated to include "policies the member will pursue" to overcome payments deficits. (Ibid., 3: 228.) In the meantime, once the Marshall Plan went into effect, the United States secured further agreement that recipients of Marshall Plan aid could not also draw on the Fund. With the Europeans effectively excluded from the Fund, its only clients were developing countries. And it was during this period, on initiatives by the United States and in response to requests for assistance by developing countries, that the Fund developed its program of "stabilization" measures: exchange depreciation, domestic austerity measures, reduced public spending, rigid conditionality. Total drawings from the Fund dropped to zero in 1950, and did not exceed 1947 levels again until 1956. With respect to liquidity, the provisions of Bretton Woods were modest and proved inadequate. The European Reconstruction Program took care of Europe's needs. But the IMF repeatedly turned aside requests for new measures to increase its own capacity to supply liquidity, maintaining that the real need was for adjustment. The dollar exchange standard emerged as a "solution" to this problem. (Strange, International Monetary Relations, pp. 93-96; Block, Origins of International Economic Disorder, chap. 5; Richard Cooper, "Prolegomena to the Choice," p. 86; and Benjamin J. Cohen, in this volume.)

${ }^{91}$ In essence, Triffin argued that if the United States corrected its balance of payments deficit, the result would be world deflation because gold production at $\$ 35$ an ounce could not adequately supply world monetary reserves. But if the United States continued running a deficit, the result would be the collapse of the monetary standard because U.S. foreign liabilities would far exceed its ability to convert dollars into gold on demand. Robert Triffin, Gold and the Dollar Crisis (New Haven: Yale University Press, 1960), which was largely a reprint of two journal articles that appeared the year before. 
under-secretary of the treasury, called "outer perimeter defenses" for the dollar. Roughly speaking, these measures were designed to make gold conversion financially unattractive, to increase the capacity of the IMF to supply liquidity, and to increase the capacity of central banks to neutralize the flow of speculative capital. The U.S. also undertook limited domestic measures to reduce its payments deficits and pressured surplus countries to revalue their currencies. By 1968, however, the dollar had become in effect inconvertible into gold; it was declared formally inconvertible in 1971.

The rise and fall of the gold-convertible dollar has placed the monetary regime in a paradoxical predicament from beginning to end. It has altered profoundly central instruments of the regime having to do with the creation of international liquidity, the system of currency reserves, and the means of ultimate settlement. It has also violated procedural norms, as unilateral action usurped collective decision. But, at the same time, it seems to have been understood and acknowledged all around that, under the material and political conditions prevailing, the substantive norms of Bretton Woods, the compromise of embedded liberalism, would not have been realized in the first place by any other means. So the regime today remains stuck with the undesired consequences of means that helped bring about a desired end. What of the long-term alternatives? Several have emerged in embryonic form. Were they to be instituted more fully, all would imply a reduced official role for the dollar and a return to the kinds of mechanisms anticipated by Bretton Woods. An internationally created reserve asset exists in the form of the special drawing right (SDR). A multiple-currency reserve system is slowly coming into being, and a dollar-substitution account has been under negotiation in the IMF. The U.S. views the SDR with disfavor and actively opposes the substitution account. It has no objection to other currencies playing a larger reserve role. As they do, however, the pressure may be expected to increase both for a substitution facility covering all reserve currencies and for a noncurrency reserve asset.

With respect to the problem of adjustment, as we saw, few provisions for, international measures to affect the economic policies of deficit or surplus countries survived the Bretton Woods negotiations. And once the new creditor-debtor relationships became established in the late 1950s, the mechanism of exchange rate changes also failed to operate effectively. There existed no means to compel surplus countries to appreciate, and among the largest deficit countries, Great Britain resisted depreciation fiercely in a vain attempt to preserve an international role for sterling while the United States, as the "Nth country," necessarily remained passive. Thus, the only real international leverage for adjustment was the conditionality provision developed by the Fund. The burden of domestic adjustment measures, therefore, fell disproportionately on the developing countries. The adjustable peg system became intolerable when imbalances in the external trade account came to be overshadowed, both as a source of problems and as a response to them, by massive movements of short-term speculative funds. This made it increasingly difficult for governments to conduct domestic macroeconomic 
policy, and to support exchange rates under pressure. When, in the late 1960s, the full attention of these funds came to be focused on the dollar as a result of dramatic deficits in the U.S. trade balance and current account, the system of fixed rates of exchange was doomed.

Shifting to floating rates required formal amendment of the Articles of Agreement of the Fund, the "slapstick comedy" act of which Triffin spoke. This is prima facie evidence of discontinuity. However, living within the Articles provided the international monetary system with an adjustment mechanism that neither functioned effectively nor fulfilled the expectations of Bretton Woods. What of the present arrangement? Three aspects bear on the argument. First, it is important to keep distinct the instrument of fixed rates from the norm of outlawing competitive currency depreciation and thus providing a framework for relatively stable exchanges. There is a good case to be made that the norm had become sufficiently well institutionalized and recourse to competitive depreciation sufficiently unnecessary given other means of influencing domestic macroeconomic factors that reliance on an increasingly burdensome instrument, which itself had begun to contribute to currency instability, could no longer be justified. ${ }^{92}$ Moreover, experience since has shown the managed float to be capable of avoiding serious disorderliness - the early months of new administrations in Washington providing the major exceptions - and to have few if any deleterious consequences for international trade. Second, floating rates were widely perceived to provide a greater cushion for domestic macroeconomic policy, which was increasingly subjected to dislocation from speculative capital flows that were often quite out of proportion to underlying economic reality. It is clear now that the degree of insulation is less than was advertised, but in the absence of uniform and fairly comprehensive capital controls it is probably as much as can be secured. Third, as an adjustment mechanism, the managed float appears to function more symmetrically than fixed rates did. Not only have surplus countries been forced to take notice, but the precipitous depreciation of the U.S. dollar caught the attention of American policy makers in the autumn of 1978 more effectively than past balance-of-payments deficits had done.

On the evolution of the IMF we can be brief; its tendency seems to be to come full circle. One does not want to exaggerate recent changes in the Fund, especially in relation to the developing countries. Nevertheless, its financing facilities have been considerably expanded, repayment periods lengthened, and conditionality provisions relaxed somewhat as well as now requiring the Fund "to pay due regard to the domestic social and political objectives" of borrowing countries. ${ }^{93}$ Moreover, decision-making power within the Fund has been reapportioned, at least to the extent of distributing

${ }^{92}$ Richard Cooper enumerates the pros and cons of these and related issues in "Prolegomena to the Choice," esp. pp. 80-81.

${ }^{83}$ Reported in The New York Times, 5 February 1980. In exploring the reasons for this change, the Times cites a "Washington wit" who "once said that the monetary fund had toppled more governments than Marx and Lenin combined." 
veto power more equitably. These changes began in the late 1950s, to make the Fund more acceptable to the Europeans once they accepted the full obligations of IMF membership; they continued in the 1960s to reflect the economic status of the European Community and Japan; and they were accelerated and aimed increasingly at the developing countries in the 1970s, as a result of the massive payments imbalances produced by new energy terms of trade and subsequent fears about the stability of the international financial system.

\section{The evolution of the trade regime}

The sense of discontinuity concerning the international trade regime is illustrated in the following excerpt from a Wall Street Journal article, entitled "Surge in Protectionism Worries and Perplexes Leaders of Many Lands":

After three decades of immense increase in world trade and living standards, exports and imports are causing tense pressures in nearly every nation and among the best of allies. The U.S. sets price floors against Japanese steel, Europe accuses the U.S. of undercutting its papermakers, the Japanese decry cheap textiles from South Korea, French farmers have smashed truckloads of Italian wine, and AFL-CIO President George Meany rattles exporters world-wide by calling free trade-'a joke. ${ }^{94}$

By now, even its most severe critics realize that "the new protectionism" is not simply the latest manifestation of "old-style" protectionism. "The emergence of the new protectionism in the Western world reflects the victory of the interventionist, or welfare, economy over the market economy. "95 However, they continue to have difficulty appreciating that the new protectionism is not an aberration from the norm of postwar liberalization, but an integral feature of it.

Today, tariffs on products traded among the industrialized countries are an insignificant barrier to trade. The Tokyo Round managed to institute further tariff cuts, and began to cope with nontariff barriers for the first time. It produced codes to liberalize such barriers resulting from domestic subsidies and countervailing duties, government procurement, product standards, customs valuation, and import licensing. All barriers to trade in civil aircraft and aircraft parts were removed. And preparations for a new GATT round, on investment and services, have commenced. What is more, the volume of world trade continues to increase and its rate of growth, though declining, still exceeds economic growth rates in several OECD countries. In sum, liberalization and growth have continued despite the erosion of postwar

${ }^{94} 14$ April 1978, as cited in Melvyn B. Krauss, The New Protectionism: The Welfare State in International Trade (New York: New York University Press, 1978), pp. xix-xx.

${ }^{95}$ Ibid., p. 36. 
prosperity, and despite the erosion of American willingness to absorb disproportionate shares of liberalized trade. ${ }^{96}$

Restraints on trade have also grown. Much of the time they take one of two forms: domestic safeguards, and "voluntary" or negotiated export restraints. Under the GATT, domestic safeguards may be invoked for balance-of-payments reasons (Article XII), or to prevent injury to domestic producers caused by a sudden surge of imports that can be attributed to past tariff concessions (Article XIX). The first of these has caused little difficulty, notwithstanding several deviations from prescribed procedure ${ }^{97}$ Article XIX lends itself to greater abuse. It permits alteration or suspension of past tariff concessions in a nondiscriminatory manner, provided that interested parties are consulted. It has been invoked with growing frequency, particularly by the U.S. and Australia. It is quite clumsy, however, because bystanders are likely to be affected and because it may involve renegotiation or even retaliatory suspension of concessions. As a result, "most governments, on most occasions, have simply short-circuited Article XIX altogether, going straight to the heart of the problem by negotiating a minimum price agreement, or a 'voluntary' export restraint with the presumably reluctant exporter who has previously been 'softened' by threats of emergency action under GATT." 98 Many of these agreements do not involve governments at all, but are reached directly between the importing and exporting industries concerned. They take place beyond the purview of the GATT and therefore are not subject to official multilateral surveillance. An attempt, made during the Tokyo Round, to conclude a safeguards code that would have provided detailed rules and procedures was unsuccessful, though negotiations are continuing. However, these problems do not afflict the entire trading order, but are sectorally specific, and a close sectoral analysis will show that there is not "any decisive movement toward protectionism. . . ."99 Lastly, so-

${ }^{96}$ Stephen D. Krasner, "The Tokyo Round: Particularistic Interests and Prospects for Stability in the Global Trading System," International Studies Quarterly 23 (December 1979).

${ }^{97}$ For example, Article XII calls for quantitative restrictions, but as time has passed import surcharges have usually been imposed. In an extremely peculiar "non-use" of Article XII, France imposed emergency measures against imports after the 1968 disturbances, while enjoying a strong reserve position and only fearing a potential balance-of-payments problem. France asked for "sympathy and understanding" from its partners in the GATT and got it. The exceptional circumstances were stressed all around, the danger of precedent was flagged, and the measures were approved and soon thereafter discontinued. The case shows, according to Curzon and Curzon, "the complicity which exists between governments when one of them is forced to take unpopular trade measures because it has a domestic problem on its hands" ("Management of Trade," p. 222). Their characterization of the reaction of others as complicitous captures the very essence of an international regime.

${ }^{98}$ Ibid., p. 225.

${ }^{99}$ Krasner, "Tokyo Round," p. 507. Krasner examines sectoral crosspressures and finds roughly this pattern: little pressure for protectionism where there is high intrasectoral trade, and even less if the sector is highly internationalized; protectionist pressures from import-competing sectors, which, however, may be balanced off by countervailing pressure from export sectors; high protectionist pressure when import competition is largely asymmetrical (pp. 502-7). Lipson, elsewhere in this volume, relates protectionist pressures to the production characteristics of sectors and finds that "sectoral protectionism is most likely in standardized, basic industries, 
called orderly marketing arrangements, of which the Longterm Textile Agreement of 1962 was the first multilateral variant, have also proliferated vastly. However, each of these has provided for a regular expansion of exports, though of course more limited than would have been obtained under conditions of "free" trade. In sum, the impact of these restraints on international trade, even by the GATT's own reckoning, has been relatively modest. ${ }^{100}$ Their purpose, moreover, has not been to freeze the international division of labor but to slow down structural change and to minimize the social costs of domestic adjustment.

With respect to the institutional role of the GATT, legal scholars in particular have lamented the passing of "effective and impartial" dispute settlement mechanisms. ${ }^{101}$ However, these mechanisms had begun to fall into disuse by the late $1950 \mathrm{~s}$ - that is, just as production and trade began to soar and serious tariff reductions were contemplated. Bilateral consultations and negotiations among instructed representatives of the disputants have since been the norm. ${ }^{102}$ It requires an extremely optimistic view of the possibilities for international law and conciliation to expect interventionist governments to behave otherwise.

\section{Assessment}

This review does not argue that the world it describes is the best of all possible worlds. I have only argued that the world has to be looked at as it is: when the regimes for money and trade are viewed in this light, the hypothesis of norm-governed change accounts for more of the variance than claims of fundamental discontinuity. Much of the observed change has been at the level of instrument rather than norm. Moreover, in most cases the new instruments are not inimical to the norms of the regimes but represent adaptations to new circumstances. And in some cases the collective response by governments to changing circumstances reflects a greater affinity to the ex-

or those with high capital requirements. It is least likely in industries where $R \& D$ is high and is oriented to changing market opportunities, where innovation in products and processes is rapid, and where the rents attributable to proprietary knowledge are short-lived" (draft manuscript).

${ }^{100}$ Two figures are pertinent here. First, the GATT estimated in the late 1970 s that import restrictions already in place or seriously threatened would affect some 3\%-5\% of world trade-which its Director General took to represent a threat to "the whole fabric of postwar cooperation in international trade policy." IMF Survey, 12 December 1977, p. 373. The second concerns the declining portion of world trade subject to MFN principles; here it must be pointed out that the overwhelming share of this decline is accounted for by customs unions and free trade areas, which, for better or for worse, have been sanctioned by the GATT. A more fundamental problem could emerge as a result of the Tokyo Round, insofar as the codes for government procurement, subsidies, and safeguards (if the last materializes) will apply only to signatories of each individual code. At this point, however, the long-term significance of this proviso remains unclear.

${ }^{101}$ See the literature cited in Lipson's article in this volume.

102 Curzon and Curzon, "Management of Trade," chap. 3. 
pectations of original regime designs than did the arrangements that prevailed in the interval.

This analysis suggests that far more continuity can attend hegemonic decline than would be predicted by the hegemonic stability thesis, provided that social purposes are held constant. ${ }^{103}$ And, since social purposes in turn reflect particular configurations of state-society relations, it suggests further that fundamental discontinuity in these regimes would be effected by an erosion in the prevailing balance of state-society relations among the major economic powers. Ironically, then, the foremost force for discontinuity at present is not "the new protectionism" in money and trade, but the resurgent ethos of liberal capitalism.

\section{Stress, contradiction, and the future}

One question remains. How enduring is embedded liberalism? Specifically, will it survive the current domestic and international economic malaise? A central ingredient in the success of embedded liberalism to date has been its ability to accommodate and even facilitate the externalizing of adjustment costs. There have been three major modes of externalization: an intertemporal mode, via inflation; an intersectoral mode, whereby pressure on domestic and international public authorities is vented into the realm of private markets; and what, for the sake of congruity, we might call an interstratum mode, through which those who are "regime makers" shift a disproportionate share of adjustment costs onto those who are "regime takers." Each of these has emerged virtually by default as a means to avoid a still worse outcome. ${ }^{104}$ The accumulated effects of these practices, however, have produced severe stresses in the world political economy. As a result, some manner of renegotiating the forms of domestic and international social accommodation reflected in embedded liberalism is inevitable. Its future, then, depends on how this is brought about. I take up the three modes of externalization in reverse order.

The compromise of embedded liberalism has never been fully extended to the developing countries. They have been disproportionately subject to the orthodox stabilization measures of the IMF, often with no beneficial results in export earnings but substantial increases in import bills and con-

${ }^{103}$ The fit between hypothesis and real world obviously is not perfect, because factors other than those examined here are also at work in the evolution of the postwar regimes. Moreover, the notion of declining American hegemony itself is very imprecise and, indeed, easy to exaggerate. See, respectively, Keohane, "Theory of Hegemonic Stability," and Susan Strange, "Still an Extraordinary Power: America's Role in a Global Monetary System" (unpublished ms., n.d.).

${ }^{104}$ I am here generalizing from Fred Hirsch's brilliant dissection of the social functions of inflation: "The Ideological Underlay of Inflation," in Fred Hirsch and John H. Goldthorpe, eds., The Political Economy of Inflation (Cambridge: Harvard University Press, 1978), esp. p. 278. 
sequent increases in domestic prices. Moreover, the liberalization produced by the GATT has benefited relatively few among them. On the whole, the developing countries did well in the 1960 s, as an adjunct to expansion in the OECD area; in the 1970s, they suffered as much from export losses to OECD markets as they did from the direct impact of increased oil prices. For a time in the mid 1970s, the developing countries managed to sustain both rates of growth and imports from the industrialized countries through additional private borrowing (their upper tranches in the IMF were left virtually untouched). However, neither could be continued indefinitely. Recent IMF reforms are important, as we have noted, but they cannot initiate economic recovery in the Third World. Nor are other means forthcoming in abundance. Thus, unlike the pattern under laissez-faire liberalism in the 19th century, under embedded liberalism lending and investment in the peripheral areas has been both relatively lower and positively correlated with core expansion rather than counterpoised to it. From the point of view of the future of embedded liberalism, the accumulated effects of this practice are not fatal-though they may prove to be very nearly fatal for some of the poorer developing countries. ${ }^{105}$ From the point of view of the established system as a whole, these effects are more in the nature of lost opportunities whose realization could have contributed to the resolution of the current economic malaise.

A second mode of externalizing adjustment costs in recent decades has been to channel pressure away from domestic and international public authorities into the domain of private markets. A prime example is the vastly increased role of international financial markets in balance-of-payments lending, as analyzed by Cohen in this volume. I argued above that the success of the monetary and trade regimes may be said to have depended in some measure on this practice, even before the recycling problems of the 1970s. But it has also come to pose a source of serious stress and potential contradiction for the monetary regime, particularly as the control of inflation has become the leading economic objective of governments. One of its consequences, discussed by Cohen, is at least a partial loss of control by governments over the process of international liquidity creation. Perhaps even more important, in attempting to achieve significant restraint in the expansion of credit and money stock effected by these markets, governments may find that the domestic economy now must shoulder a disproportionate share of the burden of adjustment. Higher domestic interest rates may have to be employed than would be warranted by domestic conditions alone, in order to compensate for the more rapid rate of expansion of the Eurofund component of the consolidated domestic and international markets. "Today the mass is still relatively small, but the speed is high. Mass times speed, as the physi-

${ }^{105}$ Hollis B. Chenery notes this exception in his otherwise optimistic outlook, "Restructuring the World Economy: Round II," Foreign Affairs 59 (Summer 1981). 
cists like to say, equals momentum." ${ }^{106}$ From the vantage point of our concerns, then, what has served as a handy and even necessary vent is threatening to undergo a means-ends reversal, with potentially serious consequences for domestic and international financial stability.

Lastly, I turn to the most pervasive and the most serious mode by which adjustment costs have been externalized, inflation. It is the most serious because it is the most likely to lead to a direct renegotiation of the modus vivendi that has characterized embedded liberalism. The international regimes for money and trade have increasingly accommodated inflation, in parallel with inflation's becoming the dominant domestic means of dealing with distributional strife in advanced capitalist societies. ${ }^{107}$ On the monetary side, the release of domestic and international money supplies from their metallic base established the essential permissive condition, facilitated by subsequent developments in the monetary regime. The primacy of domestic objectives over external financial discipline was established in the interwar period. The Bretton Woods adjustment process, when it worked, worked primarily to devalue the currencies of deficit countries and consequently to increase their domestic prices. With inconvertible reserve currencies and floating rates, whatever counterforce may have existed in the pressures that previously led to gold outflows now leads to a fall in exchange rates and thus to increases in prices and costs. On the side of the trade regime, the structure of trade that it has encouraged and the minimization of domestic adjustment costs that it allows have both had inflationary consequences, by sacrificing economic efficiency to social stability. Hirsch's conclusion concerning the monetary regime is equally applicable to both: "Critics who see these international . . . arrangements as embodying a ratchet effect for world inflation are probably right. But the relevant question is whether a liberal international economy could have been purchased at any more acceptable price." 108 This dilemma will not be easily resolved. ${ }^{109}$ However, so long as it remains understood that it is a dilemma, both parts of which have to be accommodated, the normative framework of embedded liberalism will endure as a central institutional feature of the international economic order.

${ }^{106}$ Henry C. Wallich, "Why the Euromarket Needs Restraint," Columbia Journal of World Business 14 (Fall 1979), p. 17. Wallich estimates that the Euromarkets are expanding at two to three times the rate of growth of the domestic markets of major countries (p. 23).

${ }^{107}$ Hirsch and Goldthorpe, Political Economy of Inflation, especially the chapters by Hirsch; Goldthorpe, "The Current Inflation: Towards a Sociological Account," pp. 186-214; and Charles S. Maier, "The Politics of Inflation in the Twentieth Century," pp. 37-72. The following discussion of the monetary regime draws heavily on Hirsch.

${ }^{108}$ Ibid., p. 279.

${ }^{109}$ Recent enthusiasm for simply discrediting Keynesian management and reverting to earlier monetary and fiscal "discipline" has begun to dampen under the weight of its apparent consequences. For example, in a postmortem of the 1981 summer riots across England, a junior member of the Tory government chose words that could have been taken directly from Polanyi: "This is what happens when you separate economic theory from social policy and pursue the one at the expense of the other." (Cited by David S. Broder, "Britain Offers a Grim Reminder," Manchester Guardian Weekly, 26 July 1981, p. 16.) 